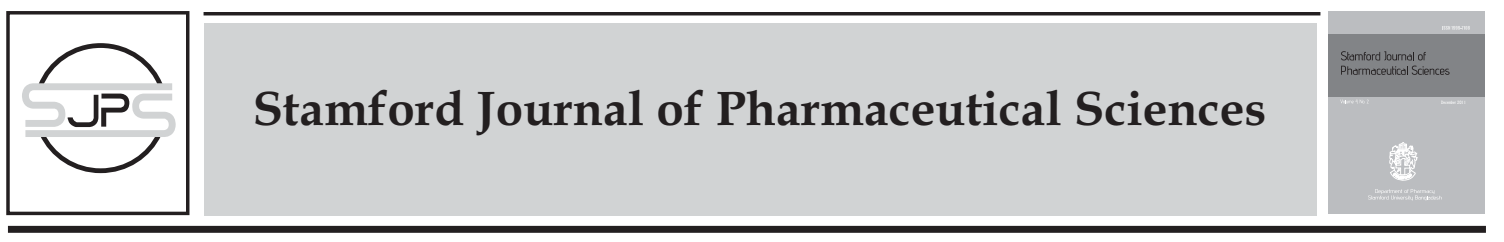

\title{
Formulation development and characterization of fast disintegrating tablets of Nimesulide
}

\author{
*Manoj M. Nitalikar'1, Dinesh M. Sakarkar² \\ 'Department of Pharmaceutics, Shri Vithal Education and Research Institute's College of Pharmacy, Pandharpur Dist., Solapur, India \\ ${ }^{2}$ Department of Pharmaceutics, S. N. Institute of Pharmacy, Pusad Dist., Yavatmal, India
}

Original Research Article

\begin{abstract}
An attempt was made to prepare fast dissolving tablets of anti-inflammatory drug Nimesulide preparing by direct compression method. The superdisintegrants Cross-carmellose and Sodium starch glycolate were used in different concentrations. Twelve formulations using those superdisintegrants at different concentration levels were prepared to access their efficiency and critical concentration level. Different evaluation parameters for tablet were studied. Tablets containing Cross-carmellose showed superior organoleptic properties and excellent in-vitro drug release as compared to other formulations. It was observed that on increasing the concentration of Cross-carmellose, the rate of disintegration was increased whereas on increasing the concentration of Sodium starch glycolate the rate of disintegration was decreased. The percentage drug release was observed as $96.32 \%$ when the concentration of Cross-carmellose was increased, whereas the same was not observed on increasing the concentration of Sodium starch glycolate.
\end{abstract}

Keywords: Formulation, characterization, fast disintegrating, tablet, nimesulide.

\section{INTRODUCTION}

Nimesulide is chemically $\mathrm{N}$-(4-nitro-2phenoxyphenyl) methane sulphonamide (Figure 1). It belongs to selective COX-2 inhibitors, with a potent analgesic activity. The pKa values of Nimesulide ranges from 5.96.56. It is freely soluble in organic polar solvents, but is sparingly soluble in aqueous solution $(0.01 \mathrm{mg} / \mathrm{ml})$ and so has low bioavailability. (Mukesh et al., 2004; Rammohan et al., 2007). It belongs to BCS class II drugs (Amidon et al., 1995; Raguia et al., 2009). For poorly soluble orally administered drugs, the rate of absorption is often controlled by the rate of dissolution. The rate of dissolution can be increased by increasing the surface area of available drug

Corresponding Author:

Manoj M. Nitalikar

Department of Pharmaceutics, Shri Vithal Education and Research Institute's College of Pharmacy,

Pandharpur Dist., Solapur, India

Contact No.: 09545553655

E-mail: manojnitalikar@lycos.com by various methods such as micronization, complexation and solid dispersion (Martin, 1993). The rate of dissolution of a drug can also be influenced by disintegration time of the tablets. Faster disintegration of tablets delivers a fine suspension of drug particles resulting in a higher surface area and faster dissolution.

Nimesulide is used for painful inflammatory conditions as antipyretic, analgesic, antiinflammatory agent. Fast-Dissolving Tablets Containing Nimesulide Micropellets were formulated and evaluated (Yadav et al., 2009). Nimesulide fast-dispersible tablets have been prepared by direct compression method (Nagar et al., 2009). Fast disintegrating tablet is solid unit dosage form that is placed in mouth, pharynx and esophagus as saliva passes down into stomach so bioavailability is greater (Chopra et al., 2009). Mouth dissolving tablets of nimesulide were formulated using vacuum drying technique (Gohel et al., 2004). The 
Table1: Formulation used in the preparation of tablets.

\begin{tabular}{|c|c|c|c|c|c|c|c|c|c|c|c|c|}
\hline $\begin{array}{l}\text { Ingredient } \\
(\mathrm{mg})\end{array}$ & $\begin{array}{c}\text { CC } \\
1\end{array}$ & $\begin{array}{c}\text { CC } \\
2\end{array}$ & $\begin{array}{c}C C \\
3\end{array}$ & $\begin{array}{c}\text { CC } \\
4\end{array}$ & $\begin{array}{c}C C \\
5\end{array}$ & $\begin{array}{c}C C \\
6\end{array}$ & $\begin{array}{c}\text { SSG } \\
1\end{array}$ & $\begin{array}{l}\text { SSG } \\
2\end{array}$ & $\begin{array}{c}\text { SSG } \\
3\end{array}$ & $\begin{array}{c}\text { SSG } \\
4\end{array}$ & $\begin{array}{c}\text { SSG } \\
5\end{array}$ & $\begin{array}{c}\text { SSG } \\
6\end{array}$ \\
\hline Nimesulide & 100 & 100 & 100 & 100 & 100 & 100 & 100 & 100 & 100 & 100 & 100 & 100 \\
\hline Croscarmellose & 0.33 & 0.66 & 0.99 & 1.32 & 1.65 & 1.98 & -- & - & -- & -- & -- & -- \\
\hline $\begin{array}{l}\text { Sodium starch } \\
\text { glycolate } \\
\text { Micro }\end{array}$ & -- & -- & -- & --- & -- & -- & 0.33 & 0.66 & 0.99 & 1.32 & 1.65 & 1.98 \\
\hline $\begin{array}{l}\text { crystalline } \\
\text { cellulose }\end{array}$ & 69.17 & 68.84 & 68.51 & 68.18 & 67.85 & 67.52 & 69.17 & 68.84 & 68.51 & 68.18 & 67.85 & 67.52 \\
\hline D-Mannitol & 30 & 30 & 30 & 30 & 30 & 30 & 30 & 30 & 30 & 30 & 30 & 30 \\
\hline Talc & 0.33 & 0.33 & 0.33 & 0.33 & 0.33 & 0.33 & 0.33 & 0.33 & 0.33 & 0.33 & 0.33 & 0.33 \\
\hline $\begin{array}{l}\text { Magnesium } \\
\text { sterate }\end{array}$ & 0.17 & 0.17 & 0.17 & 0.17 & 0.17 & 0.17 & 0.17 & 0.17 & 0.17 & 0.17 & 0.17 & 0.17 \\
\hline Total Weight & 200 & 200 & 200 & 200 & 200 & 200 & 200 & 200 & 200 & 200 & 200 & 200 \\
\hline
\end{tabular}

concept of fast dissolving tablets has emerged from the desire to provide patients with a more convenient means of taking their medication. The basic approach used in development of fast dissolving tablets is the use of superdisintegrants like cross linked carboxymethyl cellulose (Crosscarmeliose), sodium starch glycolate (Primogel, Explotab), polyvinylpyrrolidone (Polyplasdone) etc. These provide instantaneous disintegration of tablet after putting on tongue, thereby releasing the drug in saliva (Habib et al., 2000, Chang et al., 2000).

The benefits of this approach include: the drug gets faster into suspension so absorption is quicker and ultimate onset of clinical effect. Hence, a fast dissolving dosage form may be particularly suitable for conditions such as fever, pain, Inflammation etc. where a fast onset of clinical effect is required. This fast disintegrating technology of Nimesulide is convenient for administration and patient compliance for disabled, bedridden patient and for travelers and busy people, who do not always have access to water. And also the risk of choking or suffocation can be avoided. These dosage forms dissolve in the oral cavity within a minute without the need of water or chewing. This technology also offers new business opportunity like product differentiation, product promotion, and patent extension (Bhandari et al; 2008).

Most commonly used methods to prepare such tablets are freeze drying/Lyophilization (Martin, 1993), tablet molding (Schiermeier et al., 2002) and direct-compression methods (Mizumoto et al., 2005). Lyophilized tablets show a very porous structure, which causes quick penetration of saliva into the pores when placed in oral cavity. The main disadvantages of tablets produced are, in addition to the cost intensive production process, a lack of physical resistance in

Table 2: Physical study of the tablet formulations.

\begin{tabular}{|c|c|c|c|c|c|c|c|c|c|c|c|c|}
\hline $\begin{array}{l}\text { Formulation } \\
\text { parameter }\end{array}$ & $\begin{array}{c}\text { CC } \\
1\end{array}$ & $\begin{array}{c}\mathrm{CC} \\
2\end{array}$ & $\begin{array}{c}\mathrm{CC} \\
3\end{array}$ & $\begin{array}{c}\mathrm{CC} \\
4\end{array}$ & $\begin{array}{c}\mathrm{CC} \\
5\end{array}$ & $\begin{array}{c}\text { CC } \\
6\end{array}$ & $\begin{array}{c}\text { SSG } \\
1\end{array}$ & $\begin{array}{c}\text { SSG } \\
2\end{array}$ & $\begin{array}{c}\text { SSG } \\
3\end{array}$ & $\begin{array}{c}\text { SSG } \\
4\end{array}$ & $\begin{array}{c}\text { SSG } \\
5\end{array}$ & $\begin{array}{c}\text { SSG } \\
6\end{array}$ \\
\hline $\begin{array}{l}\text { Bulk density } \\
\left(\mathrm{g} / \mathrm{cm}^{3}\right)\end{array}$ & 0.420 & 0.425 & 0.430 & 0.431 & 0.433 & 0.434 & 0.420 & 0.390 & 0.423 & 0.420 & 0.399 & 0.422 \\
\hline $\begin{array}{l}\text { Weight } \\
(\mathrm{mg})\end{array}$ & 103.25 & 104.11 & 105.16 & 103.4 & 105.8 & 104.5 & 105.9 & 106.0 & 105.0 & 104.9 & 104.50 & 106.70 \\
\hline $\begin{array}{l}\text { Tapped density } \\
\left(\mathrm{g} / \mathrm{cm}^{3}\right)\end{array}$ & 0.470 & 0.472 & 0.474 & 0.474 & 0.475 & 0.476 & 0.46 & 0.465 & 0.462 & 0.460 & 0.463 & 0.464 \\
\hline $\begin{array}{l}\text { Hardness } \\
\left(\mathrm{kg} / \mathrm{cm}^{2}\right)\end{array}$ & 3.2 & 3.4 & 3.5 & 3.3 & 3.6 & 3.8 & 3.5 & 3.73 & 3.8 & 3.2 & 3.0 & 2.9 \\
\hline Friability (\%) & 0.67 & 0.69 & 0.70 & 0.72 & 0.74 & 0.76 & 0.52 & 0.54 & 0.57 & 0.59 & 0.60 & 0.62 \\
\hline $\begin{array}{l}\text { Disintegration } \\
\text { time (sec) }\end{array}$ & 90 & 88 & 85 & 82 & 78 & 76 & 95 & 93 & 92 & 90 & 87 & 85 \\
\hline $\begin{array}{l}\text { Drug release } \\
(\%)\end{array}$ & 46.61 & 50.04 & 54.82 & 58.42 & 65.92 & 96.32 & 44.72 & 46.22 & 48.40 & 50.43 & 55.60 & 58.70 \\
\hline
\end{tabular}


standard blister packs and their limited ability to incorporate higher concentrations of active drug (Schiermeier et al., 2002). Moulded tablets dissolve completely and rapidly. However, lack of strength and taste masking are of great concern. Main advantages of direct compression are low manufacturing cost and high mechanical integrity of the tablets. Therefore, direct-compression appears to be a better option for manufacturing of tablets. The fast disintegrating tablets prepared by direct compression method, in general, are based on the action established by superdisintegrants such as croscarmellose sodium and sodium starch glycolate.

In the present work, effect of superdisintegrants (such as, croscarmellose sodium and sodium starch glycolate) on disintegration time, drug content, in-vitro release and stability parameters of fast dissolving tablets of Nimesulide was studied.

\section{MATERIALS AND METHODS MATERIALS}

Drug and reagents: Nimesulide was obtained as gift sample from CIPLA Pharmaceuticals, Satara, India. Croscarmellose sodium, sodium starch glycolate, and microcrystalline cellulose, D-mannitol, Talc and magnesium stearate of analytical grade were procured from Space Chemicals, Nashik, India.

Instruments: Shimadzu UV-1700 UV/VIS spectrophotometer, USP XXIV dissolution testing apparatus II (paddle method), electronic balance (Shimadzu, AX200, Japan), Pfizer hardness tester and the Roche friabilator

\section{METHODS}

All the ingredients were passed through sieve \#60. The drug, diluents, superdisintegrant and sweetener were mixed. All the above ingredients were properly mixed together (in a poly-bag). Talc and magnesium stearate were passed through sieve \#80, mixed, and blended with initial mixture in a poly-bag. The ingredients were directly compressible. The powder blend was compressed into single punch tablet machine according to the formulations tabulated in Table 1 . The superdisintegrant croscarmellose sodium and sodium starch glycolate were used in varying concentration ranging from $0.33 \mathrm{mg}, 0.66 \mathrm{mg}$, $0.99 \mathrm{mg}, 1.32 \mathrm{mg}, 1.65 \mathrm{mg}$ and $1.98 \mathrm{mg}$ were used to prepare the tablets.

Table 3: Percent of drug release for formulation CC-6.

\begin{tabular}{ccc}
\hline SI. No. & Time (min) & Drug release (\%) \\
\hline 1 & 10 & 40.0 \\
2 & 20 & 71.5 \\
3 & 30 & 77 \\
4 & 40 & 79 \\
5 & 50 & 84 \\
6 & 60 & 98 \\
\hline
\end{tabular}

\section{EVALUATION}

The physicochemical properties of powder blend are important in tableting, so the blend was checked for the bulk density and tapped density. Tablets were evaluated for weight variation, hardness, friability, thickness, disintegration and dissolution time.

In weight variation test, twenty tablets were selected at random and average weight was determined using an electronic balance (Shimadzu, AX200, Japan). Tablets were weighed individually and compared with average weight. The Pfizer hardness tester and the Roche friabilator were used to test hardness and friability, respectively. Disintegration time was determined using disintegration testing apparatus in $900 \mathrm{ml}$ distilled water without disk at $37 \pm 0.5^{\circ} \mathrm{C}$. Results are shown in Table 2.

The release rate of Nimesulide from the tablets was determined using United State Pharmacopoeia XXIV dissolution testing apparatus II (paddle method). The dissolution test was performed using $900 \mathrm{ml}$ of phosphate buffer at $\mathrm{pH} 6.8$ as a dissolution medium at $37 \pm 0.5^{\circ} \mathrm{C}$ and $50 \mathrm{rpm}$ of paddle speed. A sample $(10 \mathrm{ml})$ of the solution was withdrawn from the dissolution apparatus at 10, 20, 30, 40, 50 and $60 \mathrm{~min}$. The samples were filtered through a $0.45 \mu \mathrm{m}$ membrane filter. Absorbance of these solutions was measured at $254 \mathrm{~nm}$ using a Shimadzu UV-1700 UV/VIS spectrophotometer. For the determination of in vitro dispersion time, one tablet was placed in a beaker containing $10 \mathrm{ml}$ of $\mathrm{pH} 6.8$ phosphate buffer at $37 \pm 0.5^{\circ} \mathrm{C}$ and the time required for complete dispersion was recorded and are shown in Figure 2 and Table 3. 
<smiles>COS(=O)(=O)c1ccc([N+](=O)[O-])cc1Oc1ccccc1</smiles>

Figure 1: N-(4-nitro-2-phenoxyphenyl) methanesul fonamide.

\section{RESULTS AND DISCUSSION}

The use of superdisintegrants for preparation of fast-dissolving tablets is highly effective and commercially feasible. These superdisintegrants accelerate disintegration of tablets by virtue of their ability to absorb a large amount of water when exposed to an aqueous environment. The absorption of water results in breaking of tablets and therefore faster disintegration occurs. This disintegration is reported to have an effect on dissolution characteristics as well.

The powder blends were studied before formation of tablet. The prepared tablets were characterized for hardness, friability, in-vitro disintegration and dissolution test. The hardness of all prepared tablet was in the range of $2.9-3.8 \mathrm{~kg} / \mathrm{cm} 2$. Friability was found to be less than $0.76 \%$, which was the indication of well mechanical resistance property of the prepared tablets. The drug release from the formulation containing highest concentration of Croscarmellose sodium (CC 6) was best as compared to others.

\section{In vitro dissolution profile of CC-6}

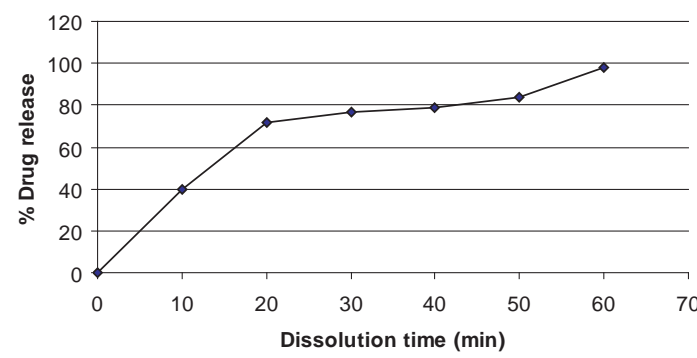

Figure 2: In vitro dissolution profile of CC-6.

\section{ACKNOWLEDGEMENTS}

The authors are thankful to Prof. Dr. B. P. Ronge, Secretary, SVERI's college of Pharmacy, Pandharpur for providing the facilities for carrying out the research project.

\section{REFERENCES}

Ali Raguia, Shoukri, Ahmed IS, Shamma RN. In vitro and in vivo evaluation of nimesulide lyophilized orally disintegrating tablets. European journal of pharmaceutics and biopharmaceutic. 2009; 73: 162-171

Amidon GL, Lennernäs H, Shah VP, Crison JR. A theoretical basis for a biopharmaceutic drug classification: the correlation of in vitro drug product dissolution and in vivo bioavailability. Pharm Res.1995; 12: 413-420.

Bhandari S, Mitapalli RK, Gannu R, Rao YM. Orodispersible tablets: An Overview. Asian Journal of Pharmaceutics 2008; 2-11

Chang R, Guo X, Burnside B A, Couch R. Fast-dissolving tablets. Pharm. Tech. 2000; 24(6): 52-58

Chopra V S, Singhai S K Formulation and Characterization of Fast-Dissolving Tablet of Nimesulide International Journal of Pharmaceutical and Clinical Research 2009; 1(2): 82-84 82

Gohel Mukesh, Patel,Madhabhai Amin Avani, Agrawal, Rikita Ruchi Dave, and Bariya Nehal, Formulation Design and Optimization of Mouth Dissolve Tablets of Nimesulide Using Vacuum Drying Technique, AAPS PharmSciTech, 2004; 5 (3):1-6.

Gupta Venkadari Rammohan, Mutalik Srinivas Patel Madhobhai M., Jani Girish K., Spherical crystals of celecoxib to improve solubility, dissolution rate and micromeritic properties, Acta Pharm. 57 (2007): 173-184.

Habib W, Khankari R, Hontz J. Fast-dissolving drug delivery systems, critical review in therapeutics. Drug Carrier Systems 2000; 17(1): 61-72.

Indranil Kumar Yadav, Durga Jaiswal, Hari Pratap Singh, Dinesh Chandra and Jain D.A. Formulation, Evaluation and Optimization of Fast-Dissolving Tablets Containing Nimesulide Micropellets, International Journal of ChemTech Research Oct-Dec 2009 Vol.1, No.4, pp 910-914,

Martin A, editor. Physical pharmacy. 4th ed. Philadelphia: Lippincott Willams and Wilkins; 1993. p. 324-62.

Mizumoto T, Masuda Y, Yamamoto T, Yonemochi E, Tarada K. Formulation design of a novel fast-disintegrating tablet. Int $\mathrm{J}$ Pharm 2005;306:

Mona Nagar, Sanjay K Singhai, Vikram Chopra, Kishor Mandage, Formulation, Evaluation and Comparision of FastDissolving Tablet of Nimesulide by Using Crospovidone as Superdisintegrant, International Journal of Pharmaceutical Sciences and Drug Research 2009; 1(3): 172-175

Mukesh Gohel, Madhabhai Patel, Avani Amin, Ruchi Agrawal, Rikita Dave, and Nehal Bariya Formulation, Design and Optimization of Mouth Dissolve Tablets of Nimesulide using Vacuum Drying Technique AAPS PharmSciTech 2004; 5 (3) Article 36

Schiermeier S, Schmidt PC. Fast dispersible ibuprofen tablets. Eur J Pharm Sci 2002; 15:295-305. 